\title{
Sediment-nutrient interactions in tropical seagrass beds: a comparison between a terrigenous and a carbonate sedimentary environment in South Sulawesi (Indonesia)
}

\author{
Paul L. A. Erftemeijer ${ }^{1,2}$, Jack J. Middelburg ${ }^{1}$ \\ ${ }^{1}$ Netherlands Institute of Ecology, Centre for Estuarine and Coastal Ecology, Vierstraat 28, 4401 EA Yerseke, The Netherlands \\ ${ }^{2}$ Catholic University Nijmegen, Toernooiveld, Nijmegen, The Netherlands
}

\begin{abstract}
The relationship between porewater nutrient concentrations and sediment characteristics was studied in seagrass beds on 2 sediment types in South Sulawesi, Indonesia. Porewater nutrient concentration gradients with sediment depth and ratios between ammonium and phosphate porewater concentrations in a terrigenous muddy sedimentary environment could be explained by modelling based on stoichiometric decomposition of organic material and molecular diffusion. Measured porewater phosphate concentrations in a carbonate sedimentary environment, however, were significantly higher (10 $\mu \mathrm{M}$ excess) in the upper few $\mathrm{cm}$ of the sediment than would be expected based on stoichiometry. This apparent phosphate enrichment is attributed to rapid regeneration of both $\mathrm{N}$ and $\mathrm{P}$ in the rhizosphere and subsequent rapid removal of ammonium by nitrification. Sampling artefacts and additional geochemical sources of dissolved $P$ (reduction of hydrous ferric oxides, calcium carbonate dissolution) could be excluded as the cause of the enrichment. The capacity of carbonate sediments to adsorb phosphate was directly related to their grain-size composition. The coarse-grained carbonate sediment in the area maintained relatively high porewater phosphate concentrations as a result of its limited adsorption capacity, in contrast to extremely low porewater phosphate concentrations reported from fine-grained carbonate sediments in the Caribbean, where strong evidence for P-limitation of seagrass growth has been found.
\end{abstract}

KEY WORDS: Geochemical processes - Grain size $\cdot$ Phosphate adsorption · Porewater nutrients $\cdot$ Sediment characteristics - Tropical seagrasses

\section{INTRODUCTION}

Light and nutrients are among the primary requirements for seagrass growth, and their availability may limit seagrass productivity (Dennison et al. 1987, Short 1987). Seagrasses are capable of taking up nutrients with both their leaves and root systems (Short \& McRoy 1984, Hemminga et al. 1991, Pérez-Lloréns et al. 1993). In tropical regions, dissolved nutrient concentrations in seawater are typically low (often below detectable limits), whereas porewater concentrations in the sediment are usually much higher. Nutrient uptake from the water column by tropical seagrass leaves is therefore considered to be insignificant relative to root uptake of nutrients from the sediments (Short 1987), although this may depend on the ratio between leaf surface area and active sorptive root surface (Smith et al. 1979, Caffrey \& Kemp 1992).

Phosphorus in the sediment may be found in porewater (soluble reactive phosphorus, or $\mathrm{PO}_{4}$ ), adsorbed to particles, bound to calcium (e.g. apatite), chemically adsorbed by iron oxyhydroxides and aluminium oxides, in distinct iron compounds, and contained in organics (Balzer 1986). Nitrogen in the sediment may be found in porewater $\left(\mathrm{NH}_{4}, \mathrm{NO}_{3}, \mathrm{NO}_{2}\right.$ and dissolved organic nitrogen), adsorbed to particles (exchangeable $\mathrm{NH}_{4}$ ), fixed in lattices of clay minerals, and contained in organics (Müller 1977, Entsch et al. 1983, D'Elia \& Wiebe 1990). The availability of dissolved nutrients in sediment porewaters is a net result of the sources 
(regeneration) and sinks (removal) of these nutrients. Decomposition of organic material is the relevant process in which large quantities of nitrogen and phosphorus are regenerated. Sorption, precipitation, diffusion and uptake by organisms are the main removal processes. Sorption of both ammonium and phosphate occurs in all types of sediment, but the extent of adsorption and the balance between adsorption and desorption may vary considerably among sediments of different mineralogical composition. Calcium carbonate sediments are known to have a high capacity to adsorb phosphate (De Kanel \& Morse 1978, Kitano et al. 1978). Consequently, the concentration of dissolved inorganic phosphorus (here referred to as phosphate) in carbonate porewaters is often very low. Porewater nutrient availability may further be influenced by the redox potential, concentration of certain chemical constituents, $\mathrm{pH}$, salinity and temperature of the porewater, and the rate of regeneration and biological consumption. Bioturbation, physical instability of the substrate and excretion of chemical substances by the seagrass roots may considerably affect balances in

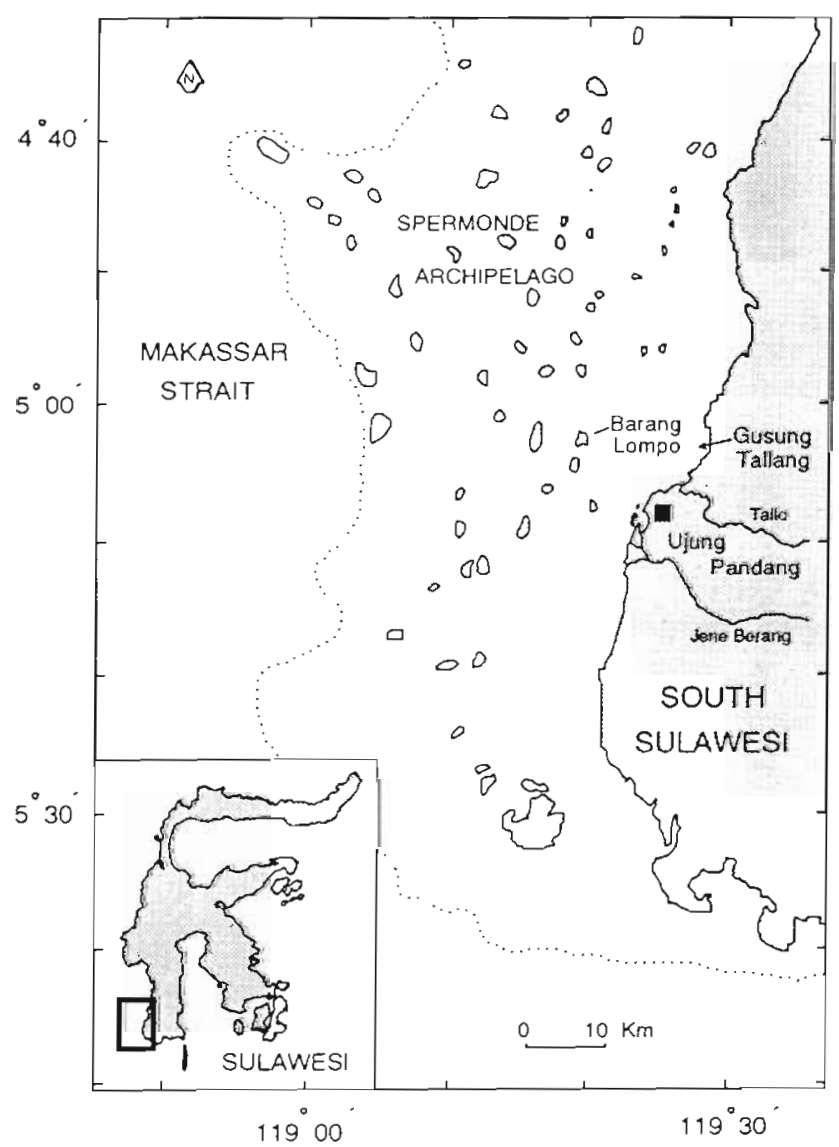

Fig. 1 The study area in Indonesia, showing locations mentioned in the text (dotted line is approximate edge of continental shelf) porewater chemistry in seagrass beds (Moriarty \& Boon 1989).

Short (1987) stressed the importance of geochemical characteristics of the sediment in the study of nutrient limitation of seagrass growth. He suggested an essential difference in nutrient cycling between terrigenous and carbonate sediments, owing to the phosphorus dynamics which are very different due to the binding (sorption) of phosphate ions to the carbonate matrix. On the basis of a literature review, Short (1987) concluded that seagrasses growing in terrigenous environments are often more typically nitrogen limited, whereas seagrasses occurring in tropical carbonate environments generally experience phosphorus limitation. Most work on this subject in the tropics has been carried out in the Caribbean, whereas data on nutrient concentrations and resources from the Indo-Pacific region are scarce.

The aim of this study is to test Short's (1987) hypothesis on phosphorus and nitrogen limitation in seagrass beds on 2 different sediment types in the IndoPacific region, and to evaluate the importance of the relationship between sediment grain-size and adsorptive capacity in the geochemical processes in controlling the availability of nutrients to seagrass growth.

\section{MATERIALS AND METHODS}

Study area. The study was conducted in the Spermonde Archipelago and adjacent coastal areas in South Sulawesi, Indonesia, during 1991. Two contrasting field sites were selected for this study: the shallowwater reef flat of Barang Lompo ( $5^{\circ} 03^{\prime} \mathrm{S}, 119^{\circ} 20^{\prime} \mathrm{E}$ ), a coral island situated about $14 \mathrm{~km}$ from the coast, and Gusung Tallang $\left(5^{\circ} 04^{\prime} \mathrm{S}, 119^{\circ} 27^{\prime} \mathrm{E}\right)$, an intertidal mudflat along the coast, located approximately $0.5 \mathrm{~km}$ north of the mouth of the Tallo River (Fig. 1). Both sites are characterized by extensive well-developed seagrass meadows dominated by Enhalus acoroides at Gusung Tallang, and by a mixture of Thalassia hemprichii and Enhalus acoroides at Barang Lompo. The reef flat at Barang Lompo is covered by at least $30 \mathrm{~cm}$ of carbonate sand, mainly derived from erosion material of the reef. This sand was bioturbated with some relief (about $10 \mathrm{~cm}$ ) resulting from numerous shrimp mounds. At Gusung Tallang, the substrate is dominated by sandy terrigenous mud, which is protected from waves and currents by a long and narrow sandbar in the north, running perpendicular to the coast. These 2 sites are considered representative of reef-associated and coastal seagrass beds in the area (Erftemeijer in press).

Methods. Each month, 24 sediment cores were collected randomly in the seagrass beds at each site over 
a 12 mo period (February 1991 to January 1992) using small hand corers (diameter $6 \mathrm{~cm}$ ) to a depth of $10 \mathrm{~cm}$. Each core was separated into $2 \mathrm{~cm}$ sections. The coinciding sections of 12 successive cores were combined to reduce spatial heterogeneity and treated as 1 sample. Accordingly, each month 2 porewater samples were obtained for each depth interval. To study porewater nutrient behaviour in deeper layers, the cores in September 1991 (Gusung Tallang) and October 1991 (Barang Lompo) were taken to an additional depth of $30 \mathrm{~cm}$. These samples were transported on ice in sealed plastic bags for further treatment in the laboratory. Plant parts, large living benthic animals and large stones were removed prior to further treatment. Within at most $4 \mathrm{~h}$ after sampling, porewaters were extracted by filtration of the samples over Schleicher \& Schuell membrane filters $(0.45 \mu \mathrm{m})$ under low pressure (1 to 3 bar) using nitrogen gas, following a slightly modified technique of Kelderman (1985), Porewater samples were subsequently filtered over $0.2 \mu \mathrm{m}$ filters and phosphate and ammonium were analysed spectrophotometrically on the same day according to methods described by Strickland \& Parsons (1972). The remainder of these sediment samples was dried for $48 \mathrm{~h}$ at $80^{\circ} \mathrm{C}$ and stored for analysis of $\mathrm{pH}$, which was determined in a $\mathrm{KCl}$ suspension. Grain-size distribution of the different depth fractions of the sandy sediment from Barang Lompo was determined by dry-sieving analysis, from which the median grain-size for each representative depth was calculated.

Separate bulk samples of the top $10 \mathrm{~cm}$ sediment layer were taken to determine porosity (calculated from water contents $=$ weight loss after drying for $48 \mathrm{~h}$ at $80^{\circ} \mathrm{C}$ ), $\mathrm{CaCO}_{3}$ content (by gas-volumetry according to Hulsemann 1966), total average grain-size distribution [by dry-sieving of sandy sediments (Barang Lompo) or by using a Malvern Particle Sizer 3600 Ec for muddy sediments (Gusung Tallang)], total carbon, organic carbon, total nitrogen, total phosphorus, exchangeable phosphorus and exchangeable ammonium. Organic carbon was analysed by applying a methodology adapted from Nieuwenhuize et al. (1993): 10 replicate sediment splits (20 mg) were treated with several drops of $25 \% \mathrm{HCl}(2 \times 20 \mu \mathrm{l})$ in small silver (Ag) containers to remove all inorganic $\mathrm{C}$ (from $\mathrm{CaCO}_{3}$ ), and then heated $\left(60\right.$ to $100^{\circ} \mathrm{C}$ ) to vaporize remaining $\mathrm{HCl}$. Organic carbon (after treatment with $\mathrm{HCl}$ drops), total carbon (without such previous treatment) and total nitrogen (no treatment) were determined on a Carlo-Erba NA $1500 \mathrm{CN}$-analyser. Total phosphorus and exchangeable phosphorus (i.e. the fraction of $P$ in the sediment that is most readily exchangeable with the dissolved $\mathrm{P}$ in the porewater) were analysed using a standard colorimetric determination of phosphate following digestion by strong oxi- dizing (hydrochloric acid + nitric acid + perchloric acid) and weak oxidizing reagents (lactic acid + acetic acid + ammonia) respectively (Allen 1974). Exchangeable ammonium was determined by a 1-step potassium chloride extraction, shaking dried sediment and $2 \mathrm{M}$ $\mathrm{KCl}$ for $2 \mathrm{~h}$ at sediment: $\mathrm{KCl}$ proportions of $1: 20$ ( $\mathrm{w}: \mathrm{v}$ ) followed by a standard spectrophotometric ammonium determination (Patriquin 1972, Rosenfeld 1979). Total $P$ and $F e$ were determined in a selection of dried sediment sections $(0-2,2-4,4-6,6-8$ and $15-18 \mathrm{~cm}$ for total P; $0-0.5,0.5-1,1-2,4-6$, and $8-10 \mathrm{~cm}$ for $\mathrm{Fe}$ ). Fe was determined by atomic spectroscopy following a microwave dissolution, according to Nieuwenhuize et al. (1991). All \pm values throughout the text refer to standard deviations of mean.

The relationship between grain size and adsorption capacity of phosphate was studied using carbonate sediments collected from the field site (Barang Lompo seagrass beds). Dried samples from the sediment were sieved in a sieving machine to yield seperate sediment fractions, of which 5 different particle size categories were used in the experiment $>1 \mathrm{~mm}, 0.6-1 \mathrm{~mm}$, $0.3-0.42 \mathrm{~mm}, 0.15-0.21 \mathrm{~mm}$ and $<0.075 \mathrm{~mm}$. Adsorbed phosphate was removed from the sediment by multiple seawater extraction in a rotation machine until no measurable $\mathrm{PO}_{4}$ (detection limit $1 \mu \mathrm{M}$ ) was retrieved in the supernatant. This procedure was also effective in equilibrating the sediments with the experimental solution. Duplicate flasks (glass) containing $12 \mathrm{~g}$ of sediment for each particle size category were soaked in $400 \mathrm{ml}$ of artificial seawater enriched at a concentration of $72 \mu \mathrm{M}$ phosphate, and thoroughly mixed in a rotation machine. Blank flasks (containing phosphate-enriched seawater without sediment) were used to determine flask wall adsorption. After $3 \mathrm{~h}$, the seawater was filtered and analysed for change in phosphate concentration. Sorption time was chosen to achieve optimal adsorption and to minimize effects of sorption on vessel walls and disaggregation of the sediment material.

\section{RESULTS}

\section{Description of the sediment}

Basic data on the composition of the sediment from the 2 sites are summarized in Table 1 . The sediment at the reef site (Barang Lompo) had a very high calcium carbonate content (nearly 100\%), is very poor in organic material (organic C: $0.29 \pm 0.05 \%$ ) and has a relatively coarse grain-size distribution (medium to coarse sand). Macroscopic identification (Milliman 1974) of the coarser fraction of the sediment (>1 mm) with the use of a binocular microscope revealed a dom- 
Table 1 Overview of sediment data $( \pm \mathrm{SD}$ ) from the 2 study sites (upper $10 \mathrm{~cm}$ of the sediment)

\begin{tabular}{|lccc|}
\hline & $\mathrm{n}$ & Barang Lompo & Gusung Tallang \\
\hline Particle size $(\mathrm{mm})(\%$ dry): & 10 & & \\
$\quad<0.075$ & & $4.7 \pm 1.3$ & $48.2 \pm 3.6$ \\
$0.075-0.105$ & & $2.5 \pm 0.7$ & $25.5 \pm 3.1$ \\
$0.105-0.15$ & & $11.5 \pm 1.5$ & $13.9 \pm 1.1$ \\
$0.15-0.21$ & & $14.9 \pm 1.6$ & $7.4 \pm 2.1$ \\
$0.21-0.3$ & & $8.7 \pm 0.8$ & $2.5 \pm 1.6$ \\
$0.3-0.42$ & & $8.4 \pm 0.7$ & $1.7 \pm 0.9$ \\
$0.42-0.60$ & & $13.1 \pm 0.7$ & $0.8 \pm 0.4$ \\
$0.60-1.0$ & & $23.1 \pm 4.6$ & 0 \\
$>1.0$ & 10 & $98 \pm 5$ & $10.8 \pm 3.7$ \\
CaCO $(\%)$ & 10 & $12.05 \pm 0.06$ & $6.72 \pm 0.06$ \\
Total C (\%) & 10 & $0.30 \pm 0.05$ & $1.89 \pm 0.06$ \\
Organic C (\%) & 4 & $27 \pm 2$ & $47 \pm 2$ \\
Water content (\% wet) & 4 & $0.53 \pm 0.04$ & $0.72 \pm 0.02$ \\
Porosity & 20 & $8.96 \pm 0.08$ & $7.87 \pm 0.08$ \\
KCl-pH & 10 & $275 \pm 17$ & $1009 \pm 22$ \\
Total P (ppm) & 10 & $87.8 \pm 3.9$ & $26.6 \pm 5.2$ \\
Exchangeable P (ppm) & 10 & $40 \pm 10$ & $80 \pm 30$ \\
Total N (ppm) & 10 & $5.54 \pm 0.47$ & $11.65 \pm 0.52$ \\
Exchangeable N (ppm) & & & \\
\hline
\end{tabular}

polychaetes and fragments of crustaceans, echinoderms and fish bones. The sediment at the coastal site (Gusung Tallang) was composed of terrigenous sandy mud. It had a $\mathrm{CaCO}_{3}$ content of $10.8 \pm 3.7 \%$ (mainly shell fragments) and contained more organic material (organic C: $1.89 \pm 0.05 \%$ ). A major proportion of this sediment consisted of weathered aluminosilicates and volcanoclastics, dominated by augite and some basic hornblende. The sediment from the Enhalus acoroides beds at Gusung Tallang exhibited little variation with respect to grain-size characteristics and consisted predominantly of fine sand-sized $(63$ to $129 \mu \mathrm{m})$ and silt-and clay-sized $(<63 \mu \mathrm{m})$ particles. Coarser sand-sized (>0.2 mm) particles constituted less than $5 \%$ of the dry weight. The sediment from the mixed seagrass beds at Barang Lompo consisted of a largely heterogenous mixture of coarse, medium and fine sand, with 58 to $72 \%$ of the particles larger than $0.2 \mathrm{~mm}$.

inance of scleractinian coral skeletal fragments, foraminifera and fragmented molluscs with smaller amounts of calcified green algae (e.g. Halimeda), serpulid

Porosity $(n=4)$ of the carbonate sand $(0.53 \pm 0.04)$ was found to be smaller than that of the terrigenous sandy mud $(0.72 \pm 0.02)$, with sediment water con-
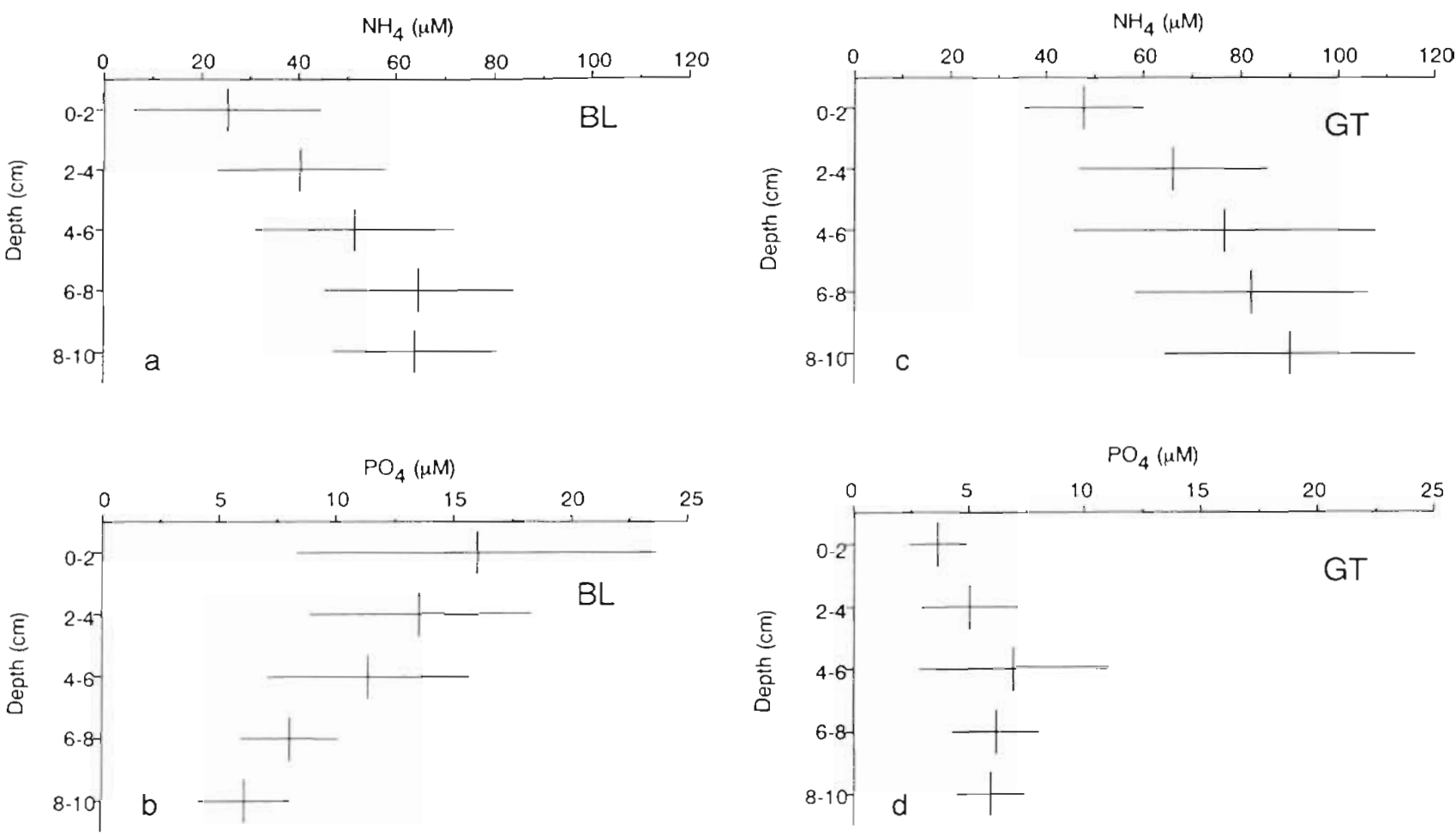

Fig. 2. Average and standard deviation of porewater nutrient concentrations in the upper $10 \mathrm{~cm}$ of the sediment from $12 \mathrm{monthly}$ duplicate sampling series at Barang Lompo (BL, carbonate) and Gusung Tallang (GT, terrigenous) seagrass beds: (a) ammonium, $B L_{i}$ (b) phosphate, BL; (c) ammonium, GT; (d) phosphate, GT ( $=24$ ) 
tents of $27 \pm 2 \%$ at Barang Lompo and $47 \pm 2 \%$ at Gusung Tallang. Sediment $\mathrm{pH}(\mathrm{KCl}$ extraction) was $8.96 \pm 0.08$ in the carbonate sand and $7.87 \pm 0.08$ in the terrigenous mud and did not show significant variation with depth (both localities). Additional punch-in pH measurements (electrode) made in fresh cores from the mud at Gusung Tallang in 1992 revealed $\mathrm{pH}$ values between $7.4(40 \mathrm{~cm}$ depth) and 7.8 (surficial sediment) with a gradual decrease of $\mathrm{pH}$ with depth.

Total $\mathrm{P}(\mathrm{n}=4)$ in the terrigenous mud $(1009 \pm 22 \mathrm{ppm})$ was nearly 4 times higher than in the carbonate sand $(275 \pm$ $17 \mathrm{ppm}$ ). In contrast, exchangeable phosphate $(\mathrm{n}=10)$, was almost 4 times higher in the carbonate sediment $(87.8 \pm$ $3.9 \mathrm{ppm})$ than in the coastal mud (26.6 \pm $5.2 \mathrm{ppm})$. Total $\mathrm{N}(\mathrm{n}=10)$ in the coastal mud $(80 \pm 30 \mathrm{ppm})$ was twice as high as in the reef sediment $(40 \pm 10 \mathrm{ppm}) . \mathrm{KCl}$ extractable ammonium ( $n=4)$ was about 2 times lower in the carbonate sediment $(5.54 \pm 0.47 \mathrm{ppm})$ than in the coastal mud (11.65 $\pm 0.52 \mathrm{ppm})$.

\section{Porewater phosphate and ammonium}

Data from 12 mo of repetitive sampling and analysis of porewater nutrients (upper $10 \mathrm{~cm}$ ) from Barang Lompo and Gusung Tallang were averaged and plotted (Fig. 2). Although there was a relatively large variation in porewater nutrient concentrations [spatial heterogeneity (in $\mu \mathrm{M}$ ): mean SD of 1.49 and 0.91 for phosphate and 6.10 and 9.13 for ammonium at Barang Lompo and Gusung Tallang respectively; temporal heterogeneity (in $\mu \mathrm{M}$ ): mean SD of 3.61 and 1.58 for phosphate and 16.53 and 17.35 for ammonium at Barang Lompo and Gusung Tallang respectively] the measurements revealed significant trends with depth that were consistent throughout the year. Porewater ammonium concentrations increased with sediment depth in both types of sediment. Analyses of samples to depths of $30 \mathrm{~cm}$ (September 1991: Gusung Tallang; October 1991: Barang Lompo) showed that ammonium concentrations increased with sediment depth, reaching a constant level at about $8 \mathrm{~cm}$ (carbonate sand) or $12 \mathrm{~cm}$ depth (coastal mud) after which the concentration remained roughly unchanged with further depth at both sites (Fig. 3). The median ammonium concentrations were $60.1 \mu \mathrm{M}$ for the carbonate site and $106.8 \mu \mathrm{M}$ for the terrigenous site. Porewater phosphate concentrations at the coastal site Gusung Tallang showed a gradual increase with sediment depth in the upper $6 \mathrm{~cm}$, reached a relatively constant level (of approximately $6 \mu \mathrm{M}$ ) between 6 and $10 \mathrm{~cm}$ depth (Figs. 2 \& 3), but increased again at greater depth (Fig. 3). The overall impression is that of an increasing trend with depth, consistent throughout the year (Fig. 2). In the carbonate sediment porewaters collected from Barang Lompo, phosphate showed maximum concentrations of 15 to $20 \mu \mathrm{M} \mathrm{PO}_{4}$ at a depth of about $2 \mathrm{~cm}$, and then decreased to relatively low levels $(<5 \mu \mathrm{M})$ in deeper layers of the sediment $(>10 \mathrm{~cm})$. Again, this trend was found to be consistent throughout the year (Fig. 2) and persisted at greater depths to $30 \mathrm{~cm}$ (Fig. 3). Median porewater phosphate concentrations were comparable at the 2 sites, 7.8 and $6.1 \mu \mathrm{M}$ at Gusung Tallang and Barang Lompo, respectively. The samples to a depth of $30 \mathrm{~cm}$ are considered to provide porewater nutrient depth profiles representative of the 2 localities and are used as such for further discussion in this paper. 


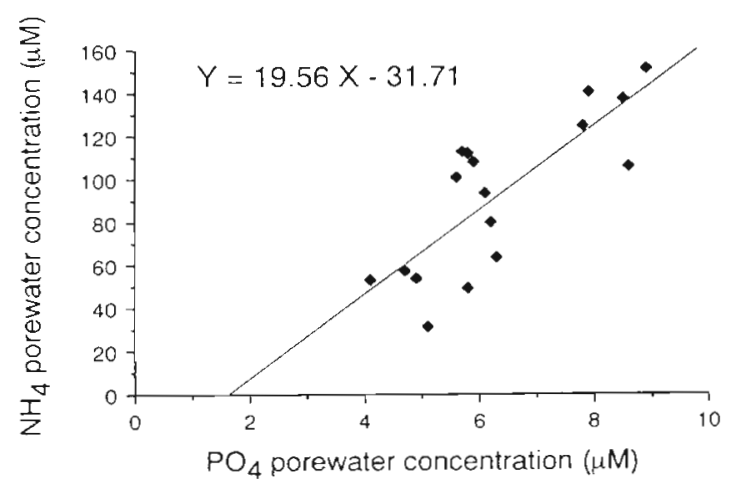

Fig. 4. Stoichiometric modelling of porewater nutrient concentrations from Gusung Tallang by linear regression of ammonium and phosphate concentrations from coinciding sediment sections (according to $\left[\mathrm{NH}_{4}\right]=19.56\left[\mathrm{PO}_{4}\right]-31.71$ ) $\left(r^{2}=0.62\right)$

From the porewater nutrient depth profiles (Fig. 3) we calculated the rate of diffusion of nutrients across the sediment-water interface. The simple diffusive flux (ionic and molecular diffusion) of a nutrient across the sediment-water interface is equal to the product of the porosity, the apparent diffusion coefficient of this nutrient and the concentration gradient between porewater and water column (Li \& Gregory 1974, McCaffrey et al. 1980). Apparent diffusion coefficients in deionized water $\left(D_{0}\right)$, taken from Li \& Gregory (1974) for a water temperature of $25^{\circ} \mathrm{C}$, were corrected for tortuosity using porosity data from Table 1 and porosity-tortuosity relationships reported by Sweerts et al. (1991). The apparent diffusion coefficients for the flux across the sediment-water interface $\left(D_{5}\right)$ thus calculated for $\mathrm{NH}_{4}$ are $376.2 \mathrm{~cm}^{2} \mathrm{yr}^{-1}$ at Barang Lompo and $397.6 \mathrm{~cm}^{2} \mathrm{yr}^{-1}$

Table 2. Primary elemental constituents (in $\%$ of dry weight) and atomic N:P ratios of seagrass plant tissue from the study sites $(n=6)$

\begin{tabular}{|lllll|}
\hline $\begin{array}{l}\text { Location } \\
\text { Seagrass species }\end{array}$ & Plant part & $\% \mathrm{~N}$ & $\% \mathrm{P}$ & $\begin{array}{c}\text { N:P } \\
\text { atomic } \\
\text { ratio }\end{array}$ \\
\hline $\begin{array}{llll}\text { Barang Lompo } \\
\text { Enhalus } \\
\text { acoroides }\end{array}$ & Leaf blades & $0.96 \pm 0.02$ & $0.11 \pm 0.07$ & $19: 1$ \\
& Sheaths & $0.86 \pm 0.14$ & $0.19 \pm 0.03$ & $10: 1$ \\
& Rhizomes & $0.40 \pm 0.08$ & $0.09 \pm 0.02$ & $10: 1$ \\
& Roots & $0.36 \pm 0.09$ & $0.05 \pm 0.01$ & $16: 1$ \\
Thalassia & Leaf blades & $1.90 \pm 0.42$ & $0.14 \pm 0.02$ & $30: 1$ \\
hemprichii & Sheaths & $0.83 \pm 0.39$ & $0.12 \pm 0.01$ & $15: 1$ \\
& Rhizomes & $0.48 \pm 0.04$ & $0.07 \pm 0.01$ & $15: 1$ \\
& Roots & $0.98 \pm 0.27$ & $0.06 \pm 0.01$ & $36: 1$ \\
Gusung Tallang & Leaf blades + & $2.71 \pm 0.14$ & $0.34 \pm 0.09$ & $18: 1$ \\
Enhalus & sheaths & $0.88 \pm 0.20$ & $0.10 \pm 0.02$ & $19: 1$ \\
acoroides & Rhizomes & $0.31 \pm 0.73$ & $0.13 \pm 0.03$ & $22: 1$ \\
& Roots & $1.31 \pm 0$. & \\
\hline
\end{tabular}

at Gusung Tallang. For $\mathrm{PO}_{4}$ these are $152.0 \mathrm{~cm}^{2} \mathrm{yr}^{-1}$ at Barang Lompo and $160.6 \mathrm{~cm}^{2} \mathrm{yr}^{-1}$ at Gusung Tallang. Water column concentrations roughly averaged $1 \mu \mathrm{M}$ for $\mathrm{PO}_{4}$ and $\mathrm{NH}_{4}$ at both sites (Erftemeijer in press). Vertical diffusion between sediment and water column was calculated from Fick's first law of diffusion: $J_{\mathrm{s}}=$ $-\varnothing D_{\mathrm{s}}(\mathrm{d} c / \mathrm{d} x)$, where $J_{\mathrm{s}}=$ flux in $\mu \mathrm{mol} \mathrm{cm}{ }^{-2} \mathrm{yr}^{-1} ; \emptyset=$ porosity of the sediment; $D_{\mathrm{s}}=$ sediment molecular diffusion coefficient for the diffusing substance in $\mathrm{cm}^{2}$ $\mathrm{yr}^{-1} ; \mathrm{d} c / \mathrm{d} x=$ initial concentration gradient in the sediment in $\mu \mathrm{mol} \mathrm{cm}{ }^{-3}$; and $x=$ sedimentary depth (in $\mathrm{cm}$ ). As such, we estimated a $\mathrm{NH}_{4}$ flux of $3.79 \mu \mathrm{mol} \mathrm{cm} \mathrm{cm}^{-2}$ $\mathrm{yr}^{-1}$ and $11.16 \mu \mathrm{mol} \mathrm{cm} \mathrm{cm}^{-2} \mathrm{yr}^{-1}$ for Barang Lompo and Gusung Tallang respectively, and a $\mathrm{PO}_{4}$ flux of 1.37 $\mu \mathrm{mol} \mathrm{cm}^{-2} \mathrm{yr}^{-1}$ and $0.46 \mu \mathrm{mol} \mathrm{cm} \mathrm{cm}^{-2} \mathrm{yr}^{-1}$ for Barang Lompo and Gusung Tallang respectively.

\section{Stoichiometric modelling}

The N:P ratio of the (decomposing) organic material can be used to predict the resulting ammonia and phosphate concentrations in interstitial waters of nearshore marine sediments and vice versa (Sholkovitz 1973, Martens et al. 1978). By plotting corresponding porewater $\mathrm{NH}_{4}$ and $\mathrm{PO}_{4}$ enrichments from the mud at Gusung Tallang, a linear stoichiometric relationship was found from which an N:P ratio of 19.6 was derived (Fig. 4). This estimated N:P ratio of decomposing organic matter corresponds well with an average $\mathrm{N}: \mathrm{P}$ ratio of $19.7 \pm 2.1$ found in living seagrass material (leaf blades + sheaths + rhizomes + roots) from the same study site (Table 2). The average N:P ratio in living seagrass material at Barang Lompo was $19( \pm 9)$. Hence it is fair to assume that the expected porewater phosphate concentration at Barang Lompo can be calculated using observed $\mathrm{NH}_{4}$ concentrations and a N:P ratio of 19 . No corrections were made to this N:P ratio to account for differences in diffusion rates and adsorption affinities between ammonium and phosphate. When calculated and observed porewater phosphate profiles are compared, a remarkable deviation occurs in the upper sediment layer (Fig. 5).

\section{Adsorption capacity}

The carbonate sediments at Barang Lompo had a relatively coarse particlesize composition (Table 1). Analysis of median particle size along a sediment depth gradient in samples from Barang 


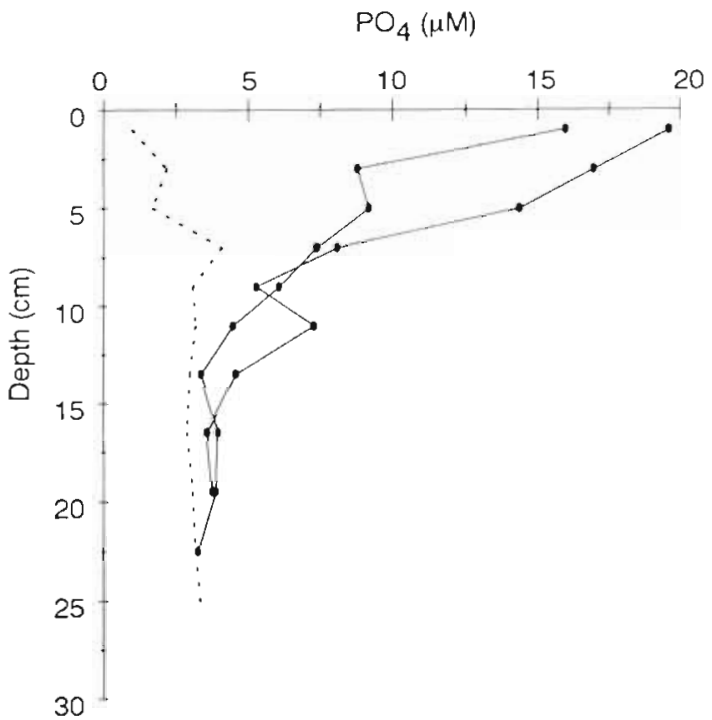

$\rightarrow$ Observed - Calculated

Fig. 5. Relationship between observed porewater phosphate concentrations in the carbonate sediments from seagrass beds at Barang Lompo and the expected porewater phosphate profile calculated from the observed ammonium profile using an N:P ratio of 19

Lompo indicated an even coarser sediment composition in deeper layers (Fig. 6). To study the relationship between particle-size and adsorption capacity, we carried out an adsorption experiment (see 'Methods'). This experiment indicated that fine-grained sediment fractions adsorbed more phosphate than coarser fractions (Fig. 7). This might explain why fine-grained carbonate sediments often maintain lower dissolved phosphate concentrations in the porewater than coarse-grained sediments.

\section{DISCUSSION}

The 2 sedimentary environments investigated in this study showed considerable differences with respect to sediment composition and nutrient availability. Total $P$ and $\mathrm{N}$ were significantly higher in the coastal muddy sediment in comparison to the carbonate sand from Barang Lompo, due to an increased terrestrial input of organic matter by the Tallo River. Exchangeable P, however, was considerably higher in the carbonate sediment, which is attributed to the stronger adsorption affinity of the carbonate matrix to phosphate in comparison to the aluminosilicate and volcanoclastic sediment particles. Exchangeable $N$ was significantly lower in the carbonate sand than in the terrigenous mud. Rosenfeld (1979) also found that less ammonium was extractable from carbonate than from terrigenous

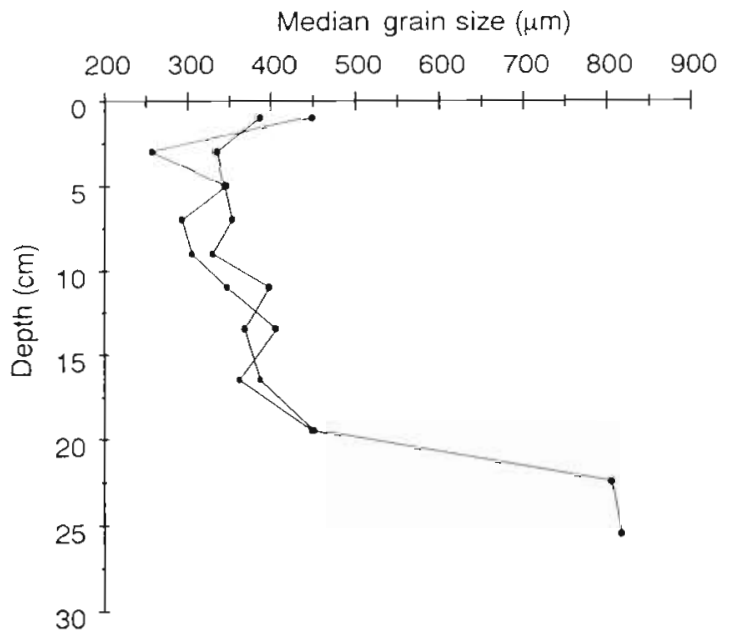

Fig. 6. Relationship between median sediment grain-size $(\mu \mathrm{m})$ and sediment depth of carbonate sediments in seagrass beds at Barang Lompo $(n=2)$

sediments of comparable dissolved ammonium concentrations and that the adsorbed ammonium in carbonate sediments was predominantly associated with organic matter.

Porewater nutrient concentration gradients with sediment depth and ratios between ammonium and phosphate porewater concentrations in the terrigenous mud at Gusung Tallang could well be explained by stoichiometric modelling based on decomposition of organic material, and molecular diffusion. Theoretically expected porewater phosphate concentrations at Barang Lompo, calculated from the observed porewater ammonium profiles and the average N:P ratio in

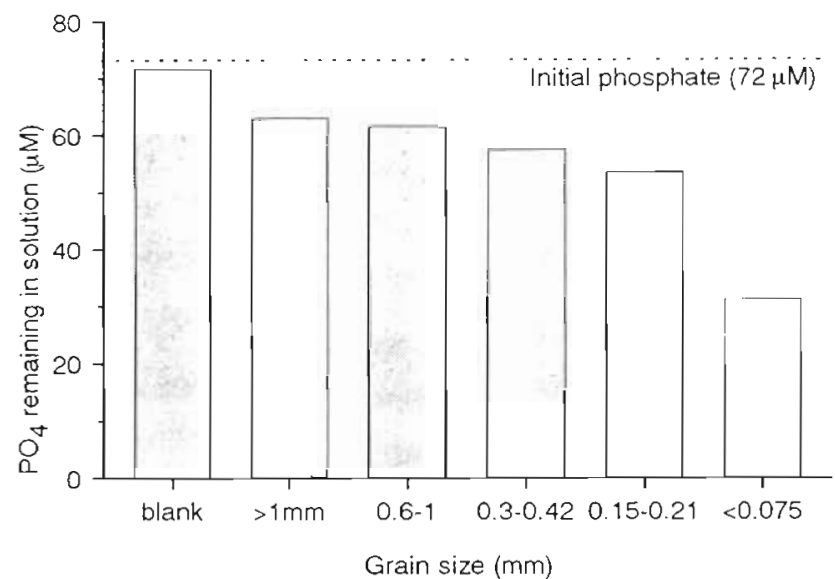

Fig. 7. Phosphate adsorption by calcium carbonate sediment (Barang Lompo) of different grain-size categories after $3 \mathrm{~h}$ incubation in an initial $\mathrm{PO}_{4}$ solution of $72 \mu \mathrm{M}$ (experimental procedure: see text). (Maximum $\mathrm{SD}<2 \mu \mathrm{M}$ ) 
plant material at this site, were significantly lower than the $\mathrm{PO}_{4}$ concentrations that were actually measured in the upper layers of the sediment. In these calculations, no corrections were made for differences in diffusion rates and adsorption affinities between ammonium and phosphate. In carbonate sediments, however, these 2 processes are generally in balance with each other for these 2 nutrients (e.g. Middelburg 1991).

This discrepancy between observed and calculated phosphate concentrations requires some detailed discussion on additional sources and sinks. It should perhaps be mentioned that the estimated phosphate excess probably represents a minimum, since there is significant downward diffusion of phosphate (see Figs. 2 \& 3). Additional dissolved P may arise from dissolution of calcium carbonate or from reduction of hydrous ferric oxides (Van Cappellen \& Berner 1988).

In the upper millimetres of the sediment, carbon dioxide and acids are produced as a result of aerobic decomposition of organic material and oxidation of reduced sulphur compounds (Froelich et al. 1979). These acids may cause dissolution of calcium carbonate at the sediment-water interface. Consequently, the phosphate adsorbed on and incorporated in these carbonate particles will also dissolve and as such result in a net enrichment of porewater phosphate. On the basis of $275 \mathrm{ppm} P$ in $\mathrm{CaCO}_{3}$ (Table 1) we estimate that the observed porewater enrichment of $10 \mu \mathrm{M}$ phosphate corresponds with a porewater enrichment of about $11 \mathrm{mM} \mathrm{Ca}$. This estimate is based on stoichiometric dissolution or desorption and equal diffusivities of $\mathrm{Ca}^{2+}$ and $\mathrm{PO}_{4}{ }^{3-}$. The estimated porewater enrichment of $\mathrm{Ca}$ $(11 \mathrm{mM})$ due to $\mathrm{CaCO}_{3}$ dissolution is almost 5 -fold the maximum enrichments due to $\mathrm{CaCO}_{3}$ dissolution that have been reported in the literature (e.g. Walter \& Burton 1990). Accordingly, it seems that the maximum enrichment of phosphate which can be attributed to $\mathrm{CaCO}_{3}$ dissolution is only of the order of $2 \mu \mathrm{M} \mathrm{PO}_{4}$.

The reduction of hydrous ferric oxides constitutes another potential source of dissolved phosphate in porewaters of sediments overlain by aerated bottom waters (Berner 1974, Van Cappellen \& Berner 1988). These hydrous ferric oxides have a very high specific surface area and are known to strongly adsorb phosphate from seawater under oxic conditions (Stumm \& Leckie 1970, Berner 1973). Under reducing conditions in the sediment, ferric-oxide reduction releases both soluble ferrous ions and phosphate into solution (Van Cappellen \& Berner 1988). This release of reactive $P$ is likely to mimic closely the changes in redox conditions (Van Cappellen \& Berner 1988). Although oxygenated microzones may occur around seagrass roots and the holes of burrowing organisms, the sediments in the study area are considered to be largely anoxic, with the exception of the upper few millimetres or perhaps
1 or $2 \mathrm{~cm}$ at the sediment-water interface. Sediments in the area smelled of hydrogen sulphide, indicating reducing anoxic conditions. Anoxia within centimetres of the sediment surface in tropical carbonate sediments was also reported by Hines \& Lyons (1982), Tribble (1988) and Walter \& Burton (1990).

Some Fe enrichment might be received from terrigenous inputs, given the fact that the carbonate study site is located at approximately $14 \mathrm{~km}$ from the mainland of Sulawesi, which is primarily volcanic in origin (De Klerk 1982). We analysed the concentration of total phosphorus and total iron in a number of samples from different depths in the sediment. The results (Table 3) indicate a slight enrichment of total P (209.7 to $266.5 \mathrm{ppm}$ ) in the upper layer of the sediment and no significant enrichment of $\mathrm{Fe}\left(0.29\right.$ to $\left.0.38 \mathrm{mg} \mathrm{g}^{-1}\right)$. Assuming a quantitative transfer of this slight excess solid-phase P (52.4 ppm) to solution, and no diffusive losses, a maximum dissolved porewater phosphate enrichment of about $4 \mu \mathrm{M}$ can be estimated using data on porosity $(0.53)$ and density (2.7 for $\mathrm{CaCO}_{3}$ ) (Tables 1 \& 3). The effects of this process should be more pronounced at the coastal locality Gusung Tallang; however at this site no phosphate enrichment of upper sediment layers was detected.

Since geochemical processes can be excluded as the cause of the phosphate enrichment with respect to ammonium in the upper few centimetres at Barang Lompo, the problem still persists. Alternative explanations or responsible processes are more likely of biological or microbiological nature. McRoy \& Barsdate (1970) experimentally demonstrated that eelgrass Zostera marina can take up phosphate with both its leaves and roots. A portion of labelled $\left({ }^{32} \mathrm{P}\right)$ phosphate absorbed by the roots was subsequently released into the water surrounding the leaves. The isotope data indicated that the reverse process also occurred, but the intensity of the former was much greater. PérezLloréns et al. (1993) reported on ${ }^{32} \mathrm{P}$ root-uptake experiments with Zostera noltii. They found that up to $70 \%$ in the light and $33 \%$ in the dark of the total amount of $\mathrm{P}$ taken up by the root-rhizomes was translocated to

Table 3. Total phosphorus $(\mathrm{n}=2)$ and total iron $(\mathrm{n}=3$ ) contents $( \pm \mathrm{SD})$ in carbonate sediment samples from Barang Lompo

\begin{tabular}{cc|cc|}
\hline $\begin{array}{c}\text { Depth } \\
(\mathrm{cm})\end{array}$ & $\begin{array}{c}\text { P total } \\
(\mathrm{ppm})\end{array}$ & $\begin{array}{c}\text { Depth } \\
(\mathrm{cm})\end{array}$ & $\begin{array}{c}\mathrm{Fe} \\
\left(\mathrm{mg} \mathrm{g}^{-1}\right)\end{array}$ \\
\hline $0-2$ & $262.1 \pm 26.2$ & $0-0.5$ & $0.29 \pm 0.06$ \\
$2-4$ & $266.5 \pm 26.2$ & $0.5-1$ & $0.33 \pm 0.10$ \\
$4-6$ & $209.7 \pm 34.9$ & $1-2$ & $0.35 \pm 0.10$ \\
$6-8$ & $209.7 \pm 26.2$ & $4-6$ & $0.38 \pm 0.08$ \\
$15-18$ & $244.7 \pm 8.7$ & $8-10$ & $0.38 \pm 0.12$ \\
\hline
\end{tabular}


the leaves (mainly to young leaves). Patriquin (1972) suggested that the sediments may temporarily buffer the supply of phosphate for Thalassia testudinum by storing seawater phosphate, taken up by the leaves of $T$. testudinum during periods of high supply, into the sediments by root excretion. It is, however, unlikely that such a pathway would contribute significantly to the phosphate pool in the sediments under investigation, because it would have to occur against the ambient concentration gradient.

There is, however, considerable difference in the root layer between Enhalus acoroides and Thalassia hemprichii. The thick rhizomes of E. acoroides bear several coarse, soft, unbranched roots without root hairs, while $T$. hemprichii bears one or more roots at each node with numerous root hairs (Kuo \& McComb 1989). At Barang Lompo, the rhizosphere is dominated by $T$. hemprichii (which occurs in high shoot densities of $2400 \pm 640$ shoots $\mathrm{m}^{-2}$ average; Erftemeijer in press), from which the rhizomes, roots and root hairs form an entangled network in the upper 6 to $8 \mathrm{~cm}$ of the sediment, with roots or rhizomes rarely penetrating deeper into the sediment. At Gusung Tallang, the rhizosphere is entirely dominated by E. acoroides (which occurs at relatively low shoot densities of $39 \pm 6$ shoots $\mathrm{m}^{-2}$ average), of which the rhizomes and long unbranched roots penetrate much deeper into the sediment (at least up to $25 \mathrm{~cm}$ in the soft mud at this site) and do not form such a compact network in the upper sediment layer.

When the majority of organic matter (detritus) in the seagrass bed at Barang Lompo is trapped in the upper layer of the sediment by the entangled rhizosphere of Thalassia hemprichii and decomposed there, this would lead to a considerable enrichment of both $\mathrm{N}$ and $\mathrm{P}$ in the upper few $\mathrm{cm}$ of the sediment in comparison to deeper layers. Several investigators have reported concentrations of soluble reactive phosphorus to be higher in the root zone of seagrass beds than in deeper zones or in nearby unvegetated areas (McRoy et al. 1972, Montgomery et al. 1979, Pulich 1982, Boon 1986) as observed at Barang Lompo. We did not, however, observe a peak in porewater ammonium concentrations at this site which might imply significant ammonium sinks in the upper few centimetres of the sediment. Assimilatory uptake by seagrass roots is likely to be an important sink for both ammonium and phosphate in the rhizospere, but would also result in lower phosphate levels. Diffusion of ammonium is significantly faster than that of phosphate, but might be compensated for by sediment adsorption, which is stronger for phosphate. Nitrification might account for a considerable removal of ammonium in the oxic upper layer of the sediment and in oxic zones around seagrass roots (Iizumi et al. 1980, Moriarty \& Boon 1989). Preliminary measurements of nitrate+nitrite concentrations in porewaters (data not shown) from Barang Lompo did not indicate significantly higher levels in the upper few centimetres and were usually below $5 \mu \mathrm{M}$. Recently, Capone et al. (1992) reported significantly lower porewater $\mathrm{NH}_{4}$ concentrations in coarse-grained carbonate sediments in comparison to fine-grained and muddy carbonate sediments of 3 reefs in the central area of the Great Barrier Reef. They suggested that shallow carbonate sands are very active sites of bacterial nitrogen transformations with turnover times of less than $1 \mathrm{~d}$. Accordingly, the apparent phosphate enrichment (based on stoichiometry) observed at Barang Lompo is related to rapid generation of both phosphate and ammonium and subsequently rapid removal of ammonium by nitrification. Ammonium removal rates may be high due to tight coupling of microbial nitrogen transformations, known to be characteristic of the rhizosphere of aquatic plants (Reddy et al. 1989).

Leaving the high phosphate concentrations in the upper few centimetres of the sediment out of discussion, the porewater phosphate concentrations below $5 \mathrm{~cm}$ depth are still relatively high in comparison to similar carbonate-rich sediments in other geographical areas. Several studies in carbonate sediments in the tropical Caribbean and Florida have reported extremely low phosphate concentrations, usually below $2 \mu \mathrm{M}$ (Patriquin 1972, Short et al. 1985, Short et al. 1990, Fourqurean et al. 1992), which are generally attributed to adsorption of phosphate onto the carbonate matrix. These findings have resulted in the hypothesis that seagrass growth on carbonate sediments is phosphorus limited. Most of these studies were, however, carried out in predominantly fine-grained sediments (fine sand, muddy carbonate or even carbonate silt). Reports on carbonate porewater phosphate concentrations that are higher than $2 \mu \mathrm{M}$ often appear to arise from coarse-grained sediments (Gaudette \& Lyons 1980, Boon 1986, Alongi 1989, McGlathery et al. 1992). This indicates that the observed differences might represent different sorptive capacities of the carbonate sediments between the locations, such as was recently suggested by McGlathery et al. (1992). The sorption capacity of carbonates is directly related to the number of surface sites available, hence the reactive surface area (Comans \& Middelburg 1987. Stumm 1992). The reactive surface area, in turn, depends on the grain size of the substrate, the smaller the grainsize, the larger the surface area (Morse \& MacKenzie 1990). Direct experimental evidence for grain-size dependent sorption on calcite has been presented by McBride $(1979,1980)$ and in this study (Fig. 7).

However, part of the differences reported in the literature might also be accounted for by differences in methodologies applied to collect porewaters, with sippers or comparable in situ suction devices generally 
yielding lower concentrations than core squeezing or centrifugation techniques (Patriquin 1972, Rosenfeld 1979, Gaudette \& Lyons 1980, Entsch et al. 1983, Short et al. 1985, Morse et al. 1987, Alongi 1989, Short et al. 1990, Powell et al. 1991, Fourqurean et al. 1992, McGlathery et al. 1992). Porewater sampling artefacts of squeezing methods have been evaluated recently by De Lange et al. (1992). Oxidation during sample treatment may result in the formation of ferric hydroxides which strongly adsorb phosphate ions. As such, oxidation artefacts - if they do occur - will result in lower, rather than higher porewater phosphate concentrations. The squeezing of root fluids when squeezing with very high pressures ( 150 to 350 bar) may result in some increase of dissolved nutrient concentrations in the porewater (Bolliger et al. 1992), but is not likely to occur when using a very low pressure (such as 1 to 3 bar used in our study). Moreover, it does not seem logical why this would be specifically the case for phosphorus (high $\mathrm{PO}_{4}$ enrichment) and not for nitrogen (no $\mathrm{NH}_{4}$ enrichment) and would only occur in samples from carbonate sediments. It is therefore concluded that the increased phosphate concentration in the upper sediment at Barang Lompo is not a sampling artefact caused by the squeezing technique applied.

The relatively high availability of phosphate in porewaters from coarse-grained carbonate sediments in seagrass beds in the study area is in contrast to the general assumption that seagrass growth on carbonate sediment is phosphorus-limited (Short 1987). Nutrient enrichment experiments in seagrass beds on carbonate sediments by Short et al. $(1985,1989)$ and Fourqurean et al. (1992) have found clear evidence of phosphorus limitation, but they were all working in fine-grained sedimentary environments (carbonate mud and silt). In their study on nutrient limitation of the rhizophytic macroalga Penicillus capitatus, associated with subtropical seagrass meadows on carbonate sediments in Bermuda, McGlathery et al. (1992) found evidence of nitrogen-limitation. They observed that $P$. capitatus may acquire nutrients directly from sediment sources via rhizoid holdfasts. They suggested that the limited adsorptive capacity of the relatively coarse carbonate sediment in the area resulted in relatively high porewater phosphorus concentrations. Recent enrichment bio-essays in seagrass beds on coarse-grained carbonate sediments in South Sulawesi revealed no evidence of P-limitation (P. L. A. Erftemeijer, J. Stapel, M. J. E. Smekens \& W. M. E. Drossaert unpubl.).

Apparently not all carbonate-rich tropical sediments induce phosphorus limitation of benthic macrophytes. The present study has shown that the grain-size of the sediment is one of the primary factors determining the availability of phosphate in a tropical carbonate sedimentary environment. In addition, it is speculated that the quality of the root zone (depth penetration, root density, presence or absence of root hairs) and the rate of microbial nitrogen transformation processes may be of considerable importance in regulating the availability of nutrients in a seagrass meadow.

Acknowledgements. Prof. Dr P.H. Nienhuis and Prof. Dr C. den Hartog provided valuable comments on earlier drafts of this manuscript. Eric Wessel assisted in the preparation of the figures. Joop Nieuwenhuize, Yvonne E.M. Maas, Jaap van Liere, Carla Poley-Vos, Johan van de Sande and Jan Sinke are thanked for their analytical support. Inayah Yasir, Wim Drossaert and Marret Smekens assisted in the fieldwork. This study greatly benefitted from preliminary experiments by Dwi Juli Puspitasari, Yuriza Noviatri, Ronny Horax, Wim Drossaert and Marret Smekens, and from fruitful discussions with Dr Alfian Noor (UNHAS). This study would not have been possible without the financial support provided by the Netherlands Foundation for the Advancement of Tropical Research (WOTRO, grant W84-293). Communication no. 668 of the Netherlands Institute of Ecology, Centre for Estuarine and Coastal Ecology, Yerseke, The Netherlands.

\section{LITERATURE CITED}

Allen, S. E. (ed.) (1974). Chemical analysis of ecological materials. Blackwell, Oxford

Alongi, D. M. (1989). Benthic processes across mixed terrigenous-carbonate sedimentary facies on the central Great Barrier Reef continental shelf. Cont. Shelf Res. 9: 629-663

Balzer, W. (1986). Forms of phosphorus and its accumulation in coastal sediments of Kieler Bucht. Ophelia 26: 19-35

Berner, R. A. (1973). Phosphate removal from seawater by adsorption on volcanic ferric oxides. Earth Planet. Sci. Lett. 18: 77-86

Berner, R. A. (1974). Kinetic models for the early diagenesis of nitrogen, sulfur, phosphorus, and silicon in anoxic marine sediments. In: Goldberg, E. D. (ed.) The sea, Vol. 5. John Wiley \& Sons, New York, p. 427-450

Bolliger, R., Brandl, H., Höhener, P., Hanselmann, K. W., Bachofen, R. (1992). Squeeze-water analysis for the determination of microbial metabolites in lake sediments comparison of methods. Limnol. Oceanogr. 37: 448-455

Boon, P. I. (1986). Nitrogen pools in seagrass beds of Cymodocea serrulata and Zostera capricorni in Moreton Bay, Australia. Aquat. Bot. 24: 1-19

Caffrey, J. M., Kemp, W. M. (1992). Influence of the submerged plant, Potamogeton perfoliatus, on nitrogen cycling in estuarine sediments. Limnol. Oceanogr. 37 : 1483-1495

Capone, D. G., Dunham, S. E., Horrigan, S. G., Duguay, L. E. (1992). Microbial nitrogen transformations in unconsolidated coral reef sediments. Mar. Ecol. Prog. Ser. 80: 75-88

Comans, R. N. J., Middelburg, J. J. (1987). Sorption of trace metals on calcite: applicability of the surface precipitation model. Geochim. Cosmochim. Acta 51: 2587-2591

Dennison, W. C., Aller, R. C., Alberte, R. S. (1987). Sediment ammonium availability and eelgrass (Zostera marina) growth. Mar. Biol. 94: 469-477

De Kanel, J., Morse, J. W. (1978). The chemistry of orthophosphate uptake from seawater on to calcite and aragonite. Geochim. Cosmochim. Acta 42: 1335-1340

De Klerk, L. G. (1982). Zeespiegels, riffen en kustvlakten in zuidwest Sulawesi, Indonesië; een morfogenetischbodemkundige studie (Sea levels, reefs and coastal plains 
of southwest Sulawesi, Indonesia; a morphogenetic-pedological study). Ph.D. thesis, University of Utrecht

De Lange, G. J., Cranston, R. E., Hydes, J. D., Boust, D. (1992). Extraction of pore water from marine sediments: a review of possible artifacts with pertinent examples from the North Atlantic. Mar. Geol. 109: 53-76

D'Elia, C. F., Wiebe, W. J. (1990). Biogeochemical nutrient cycles in coral-reef ecosystems. In: Dubinsky, $Z$. (ed.) Coral reefs. Ecosystems of the world 25. Elsevier, Amsterdam, p. $49-74$

Entsch, B. K., Boto, G., Slim, R. G., Wellington, T J. (1983). Phosphorus and nitrogen in coral reef sediments. Limnol. Oceanogr. 28: 465-476

Erftemeijer, P. L. A. (in press). Differences in nutrient concentrations and resources between seagrass communities on carbonate and terrigenous sediments in South Sulawesi, Indonesia. Bull. mar. Sci. 54 (1)

Fourqurean, J. W., Zieman, J. C., Powell, G. V. N. (1992). Relationships between porewater nutrients and seagrasses in a subtropical carbonate environment. Mar. Biol. 114: $57-65$

Froelich, P. N., Klinkhamer, G. P., Bender, M. L., Luedtke, N. A., Heath, G. R., Cullen, D., Dauphin, P., Hammond, D., Hartman, B., Maynard, V. (1979). Early oxidation of organic matter in pelagic sediments of the eastern equatorial Atlantic: suboxic diagenesis. Geochim. Cosmochim. Acta 43: 1075-1090

Gaudette, H. E., Lyons, W. B. (1980). Phosphate geochemistry in nearshore carbonate sediments: a suggestion of apatite formation. SEPM Spec. Pub. 29: 215-225

Hemminga, M. A., Harrison, P. G., van Lent, F. (1991). The balance of nutrient losses and gains in seagrass meadows. Mar. Ecol. Prog. Ser. 71: 85-96

Hines, M. E., Lyons, W. B. (1982). Biogeochemistry of nearshore Bermuda sediments. I. Sulphate reduction rates and nutrient generation. Mar. Ecol. Prog. Ser. 8: 87-94

Hulsemann, J. (1966). On the routine analysis of carbonates in unconsolidated sediments. J. sedim. Petrol 36: 622-625

lizumi, H., Hattori, A., McRoy, C. P. (1980). Nitrate and nitrite in interstitial waters of eelgrass beds in relation to the rhizosphere. J, exp. mar. Biol. Ecol. 47: 191-201

Kelderman, P. (1985). Nutrient dynamics in the sediment of Lake Grevelingen (SW Netherlands). Ph.D. thesis, University of Groningen

Kitano, Y., Okumura, M., Idogaki, M. (1978). Uptake of phosphate ions by calcium carbonate. Geochem. J. 12: 29-37

Kuo, J., McComb, A. J. (1989). Seagrass taxonomy, structure and development. In: Larkum, A. W. D., McComb, A. J., Shepherd, S. A. (eds.) Biology of seagrasses. A treatise on the biology of seagrasses with special reference to the Australian Region. Aquatic Plant Studies No. 2. Elsevier, Amsterdam, p. 6-73

Li, Y. H., Gregory, S. (1974). Diffusion of ions in sea water and in deep sea sediments. Geochim. Cosmochim. Acta 38: $703-714$

Martens, C. S., Berner, R. A., Rosenfeld, J. K. (1978). Interstitial water chemistry of anoxic Long Island Sound sediments. 2. Nutrient regeneration and phosphate removal. Limnol. Oceanogr. 23: 605-617

McBride, M. B. (1979). Chemisorption and precipitation of $\mathrm{Mn}^{2+}$ at $\mathrm{CaCO}_{3}$ surfaces. Soil Sci. Soc. Am. J. 43: 693-698

McBride, M. B. (1980). Chemisorption of $\mathrm{Cd}^{2+}$ on calcite surfaces. Soil Sci. Soc. Am. J. 44: 26-28

McCaffrey, R. J., Myers, A. C., Davey, E., Morrison, G., Bender, M., Luedtke, N., Cullen, D., Froelich, P., Klinkhammer, G. (1980). The relation between pore water chemistry and benthic fluxes of nutrients and manganese in Narragansett Bay, Rhode Island. Limnol. Oceanogr. 25: 31-44

McGlathery, K. J., Howarth, R. W., Marino, R. (1992). Nutrient limitation of the macroalga, Penicillus capitatus, associated with subtropical seagrass meadows in Bermuda. Estuaries 15: 18-25

McRoy, C. P., Barsdate, R. J. (1970). Phosphate absorption in eelgrass. Limnol. Oceanogr. 15: 6-13

McRoy, C. P., Barsdate, R. J., Nebert, M. (1972). Phosphorus cycling in an eelgrass (Zostera marina L.) ecosystem. Limnol. Oceanogr. 17:58-67

Middelburg, J. J. (1991). Organic carbon, sulphur, and iron in recent semi-euxinic sediments of Kau Bay, Indonesia. Geochim. Cosmochim. Acta 55: 815-828

Milliman, J. D. (1974). Marine carbonates. Recent sedimentary carbonates, Part 1. Springer-Verlag, Berlin

Montgomery, J. R., Zimmerman, C. F., Price, M. T. (1979). The collection, analysis and variation of nutrients in estuarine porewater. Estuar. coast. Shelf Sci. 9: 203-224

Moriarty, D. J. W., Boon, P. I. (1989). Interactions of seagrasses with sediment and water. ln: Larkum, A. W. D., McComb, A. J., Shepherd, S. A. (eds.) Biology of seagrasses. Aquatic Plant Studies 2. Elsevier, Amsterdam, p. 500-535

Morse, J. W., Zullig, J. J., Iverson, R. L., Choppin, G. R. Mucci, A., Millero, F. J. (1987). The influence of seagrass beds on carbonate sediments in the Bahamas. Mar. Chem. 22: $71-83$

Morse, J. W., MacKenzie, F. T. (1990). Geochemistry of sedimentary carbonates. Developments in sedimentology No. 48, Elsevier, Amsterdam

Müller, P. J. (1977). C/N ratios in Pacific deep-sea sediments: effect of inorganic ammonium and organic nitrogen compounds sorbed by clays. Geochim. Cosmochim. Acta 44 $765-776$

Nieuwenhuize, J., Maas, Y. E. M., Middleburg, J. J. (1993). Rapid analysis of organic carbon and nitrogen in particulate materials. Mar. Chem. (in press)

Nieuwenhuize, J., Poley-Vos, C. H., van den Akker, A. H. van Delft, W. (1991). Comparison of microwave and conventional extraction techniques for the determination of metals in soils, sediment and sludge samples by atomic spectrometry. Analyst 116: 347-351

Patriquin, D. G. (1972). The origin of nitrogen and phosphorus for the growth of the marine angiosperm Thalassia testudinum. Mar. Biol. 15: 36-46

Pérez-Lloréns, J. L., de Visscher, P., Nienhuis, P. H., Niell, F. X. (1993). Light-dependent uptake, translocation and foliar release of phosphorus by the intertidal seagrass Zostera noltii Hornem. J. exp. mar. Biol. Ecol. 166: $165-174$

Powell, G. V. N., Fourqurean, J. W., Kenworthy, W. J., Zieman, J. C. (1991). Bird colonies cause seagrass enrichment in a subtropical estuary: observational and experimental evidence. Estuar. coast. Shelf Sci. 32: 567-579

Pulich, W. M. (1982). Culture studies of Halodule wrightii Aschers. Edaphic requirements. Bot. Mar. 25: 477-482

Reddy, K. R., Patrick, W. H., Lindau, C. W. (1989). Nitrification-denitrification at the plant root-sediment interface in wetlands. Limnol. Oceanogr. 34: 1004-1013

Rosenfeld, J. K. (1979). Ammonium adsorption in nearshore anoxic sediments. Limnol. Oceanogr. $24: 356-364$

Sholkovitz, E. (1973). Interstitial water chemistry of the Santa Barbara Basin sediments. Geochim. Cosmochim. Acta 37: 2043-2073

Short, F. T. (1987). Effects of sediment nutrients on seagrasses: literature review and mesocosm experiment. Aquat. Bot. 27: 41-57 
Short, F. T., McRoy, C. P. (1984). Nitrogen uptake by leaves and roots of the seagrass Zostera marina $\mathrm{L}$. and its epiphytes. Botanica mar. 27: 547-555

Short, F. T., Davis, M. W., Gibson, R. A., Zimmerman, C. F. (1985). Evidence for phosphorus limitation in carbonate sediments of the seagrass Syringodium filiforme. Estuar. coast. Shelf Sci. 20: $419-430$

Short, F. T., Dennison, W. C., Capone, D. G. (1990). Phosphorus-limited growth of the tropical seagrass Syringodium filiforme in carbonate sediments. Mar. Ecol. Prog. Ser. 62: $169-174$

Smith, G. W., Hayasaka, S. S., Thayer, G. W. (1979). Root surface area measurements of Zostera marina and Halodule wrightii. Botanica mar. 22: 347-358

Strickland, J. D. H., Parsons, T. R. (1972). A practical handbook of seawater analysis. Bull. Fish. Res. Bd Can. 167: 1-311

Stumm, W. (1992). Chemistry of the solid-water interface Processes at the mineral-water and particle-water inter-

This article was submitted to the editor face in natural systems. $\mathfrak{J}$. Wiley \& Sons, New York

Stumm, W., Leckie, J. O. (1970). Phosphate exchange with sediments; its role in the productivity of surface waters Advances in water pollution research, Vol. 2. Pergamon Press, New York, III 26/1-26/16

Sweerts, J. P. R. A., Kelly, C. A., Rudd, J. W. M., Hesslein, R. Cappenberg, T. E. (1991). Similarity of whole-sediment molecular diffusion coefficients in freshwater sediments of low and high porosity. Limnol. Oceanogr. 36: 335-342

Tribble, G. W. (1988). Geochemistry of reef interstitial waters Pacif. Sci. 42: 135-136

Van Cappellen, P., Berner, R. A. (1988). A mathematical model for the early diagenesis of phosphorus and fluorine in marine sediments: apatite precipitation. Am. J. Sci. 288 289-333

Walter, L. M., Burton. E. A. (1990). Dissolution of recent platform carbonate sediments in marine pore fluids. Am. $J$ Sci. 290: 601-643

Manuscript first received: June 14, 1993

Revised version accepted: September 14, 1993 